\title{
Few Aspects of Government Primary School Environment at Hathazari Upazilla of Chittagong
}

\section{Jalal Uddin* \\ Shaibal Barua \\ Qudrat-E-Elahi \\ Shahid Uddin}

Department of Community Medicine \& Public Health Chattagram Maa-O-Shishu Hospital Medical College Chittagong, Bangladesh.
*Correspondence to:

\section{Professor M Jalal Uddin}

Department of Community Medicine \& Public Health Chattagram Maa-O-Shishu Hospital Medical College Agrabad, Chittagong, Bangladesh.

Mobile: +8801819909464

Email: drialal65@gmail.com

\begin{abstract}
School health environment is very important for school students. To observe existing school environment we conducted the study. A total of 11 government primary school of hathazari upazilla were studied to observe about few aspects of school environment. The study was conducted during first week of May, 2012. Purposively selected primary schools were physically surveyed by the investigators. The result was as follows: Average students 373, average teachers 8.73 and average staffs were 0.45 . Average school area was 23 decimal and average floor space was $2230 \mathrm{sft}$. $82 \%$ schools were provided with tube wells and $100 \%$ school had toilet facilities. Only $18 \%$ schools provided mid-day meal. Electricity was connected with all schools. Cleanliness was satisfactory in 55\% schools and $82 \%$ schools were found fenced. There was gap between standard and existing facilities. So, it should be minimized.
\end{abstract}

Key words: Health environment; health program; comprehensive health care.

\section{INTRODUCTION}

School environment is one of the important components of school health program. Main objective of school health program is to provide comprehensive health care to school students in order to prepare them for entry into adulthood ${ }^{1}$. Other components are screening and periodic check up of students, training of school teachers and staffs etc.

Environment is the centre point of health and disease. Students stay at school for 6-8 hours in a day. So, school environment deserves utmost importance in context of health and disease of school students. To observe into the matter we had under taken the subject.

This study will be able to focus into the problems of school environment so that competent authority can take effective measures to solve the problems and thus health of school students will be significantly improved.

\section{MATERIALS \& METHODS}

It was a cross sectional type of observational study. 11 government primary schools were purposively selected. A pre-tested check list was used to collect data. Trained medical students collected data. Data was managed manually. Managed data was presented with tables.

\section{Observation and presentation}

The results were as follows: Average students 373 (range 192-665), average teachers 8.73 (range 6-12) and average staffs were 0.45 ( range 0-2). Average school area was 23 decimal (range 22-33 decimals) and average floor space was 2230 square foot (sft) (range 1800- $3200 \mathrm{sft}$ ). Mid-day meal was provided in 18\% schools only. Eighty two percent schools were provided with tube wells and $100 \%$ school had toilet facilities. Electricity was connected with all schools. Cleanliness was satisfactory in $55 \%$ schools and $82 \%$ schools were found fenced. 
Table 1: Few aspects of primary school environment at hathazari upazilla

\begin{tabular}{lc} 
Aspects & Quantity \\
Average students & 373 \\
Average teachers & 8.73 \\
Average staffs & 0.45 \\
Average school area & 23 decimals \\
Average floor space & $2230 \mathrm{sft}$. \\
Mid-day meal & $18 \%$ \\
Availability of tube well & $82 \%$ \\
Availability of toilets & $100 \%$ \\
Electricity connection & $100 \%$ \\
Fencing & $82 \%$ \\
Satisfactory cleanliness & $55 \%$ \\
\hline
\end{tabular}

Source: survey report, 2012

\section{DISCUSSION}

Uniformity was absent in different aspects of school environment. Teacher, student and staffs were not proportionate. In some schools there was gross disparity between teacher student ratios. Average teacher student ratio was 1:43. No auxiliary staff (MLSS) was found in 45\% of schools. Playground was found significantly small. It was average $1 / 3$ of the minimum requirement i.e 16 decimals. Play ground should be $1 / 2$ to 1 acre. Safe drinking water is a dire need but $18 \%$ schools were lacking of safe source. Toilet facilities were found disproportionate in respect of student number. All schools were connected with electricity but load shedding was observed in $45 \%$ schools. General cleanliness was not satisfactory in $45 \%$ schools. No auxiliary staff was there. Fencing must be there in every school particularly main road side schools though $18 \%$ schools were lacking of fencing. Due to scarcity of recent study on school environment we could not validate our study results.

\section{CONCLUSION}

Good environment is the prime factor for good health. So, it should be according to the standard one. Competent authority should take necessary measures to solve the existing problems of school environment.

\section{DISCLOSURE}

All the authors declared no competing interest.

\section{REFERENCES}

1. Park. Preventive and Social medicine. Jabalpur(India): Banarashidas bhanot: 2011.

Rashid, Khabir and Hyder. Text book of Community medicine and Public health. Dhaka: RHM publishers: 2007. 